\title{
Sensory perception of the fermented goat milk: potential application of the DSC method
}

\author{
Martha Eunice de BESSA ${ }^{1 *}$, Miriam Pereira RODARTE², Marcelo Henrique OTÊNIO ${ }^{3}$, Paulo Cesar STRINGHETA \\ Juliana Mauricio de OLIVEIRA², Jucélia Silva BARBOSA ${ }^{5}$, Miriam Aparecida de Oliveira PINTO²
}

\begin{abstract}
Goat milk and its derivatives present proven beneficial health properties; however, some sensory aspects associated to consumers' expectations restrict the consumption growth for these products. In this work, fermented caprine milk formulations have been evaluated utilizing the methodology of Discourse of the Collective Subject (Discurso do Sujeito Coletivo - DSC) associated to sensory analysis, in order to evaluate the perception of fermented caprine milk by consumers. The physicochemical and microbiological requisites of the fermented milk formulations evaluated during the storage, were according to current legislation. The probiotic characteristics of evaluated formulations were preserved, presenting viable cells counts for Lactobacillus acidophilus LA-5, Bifidobacterium BB-12, and Streptococcus thermophilus higher than $1 \times 10^{6} \mathrm{CFU} / \mathrm{mL}$, along 28 days of storage. The Discourse of the Collective Subject results have shown that the typical taste and flavor, present in products derived from caprine milk, did not influence the purchase intention, which was expressive for all fermented milks. The Discourse of the Collective Subject has elucidated the consumers' perspective, determining then both, the consumers' profile and the factors interfering on the acquisition of fermented caprine milk.
\end{abstract}

Keywords: Discourse of the Collective Subject; caprine milk; consumer.

Practical Application: The Discourse Collective Subject affordable, innovative and the consumer opinion, and the purchase intent.

\section{Introduction}

The caprine milk and its derivatives have large potential for insertion in the growing ascension market of healthy food, as they present nutritional properties, high digestibility, and low capacity for allergic reaction induction, being therefore indicated to children, adults, elderly, and people with food restriction (Almeida et al., 2009; Villalobos, 2005).

Probiotic bacterias are potential CLA producers, and it has been employed in increasing ruminant animals diet in order to increase the production of CLA, which among other things is able to inhibit the initiation of carcinogenesis and development of tumors, strengthens the immune system and reduces risk of atherosclerosis in humans (Apás et al., 2015).

Dairy products represent the most important food segment alleging functional properties (Oliveira, 2009). The utilization of goat milk contributes for dairy market diversification, allowing for the development of fermented products with differentiated sensory characteristics, as compared to products based on cows' milk. However, particular characteristics of goat milk, such as its typical taste and flavor, which result from high levels of short chain fatty acids such as hexanoic (or caproic), caprylic, and decanoic (or capric) acid, effectively decrease its acceptance by populations unacquainted with its regular consumption (Alves \& Boog, 2007; Cenachi \& Pinto, 2012).

Enzymes such as proteases and lipases produced by microorganisms psicotroficos generate smaller called FFA compounds that increase the intensity of flavor in milk stored capric influencing the flavor and decreasing acceptance by consumers milk (Fonseca et al., 2013).

Both, the knowledge about consumers' food preferences and the evaluation of product prototypes, represent important tools for the identification of different segments of dairy market and their respective potentialities (Ribeiro et al., 2010). The anticipation of consumer acceptance or rejection, by means of the analysis of intrinsic (not sensory characteristics, such as physicochemical properties) and extrinsic (sensory characteristics) factors influencing consumer's behavior, contributes for the definition of a standard for identity, selection, and research \& development of new products. The study of these factors, which are utilized by different knowledge areas and applied in the development or improvement of food products, makes

Received 25 Oct., 2015

Accepted 17 Aug., 2016

${ }^{1}$ Centro Superior de Ensino de Juiz de Fora - CES/JF, Juiz de Fora, MG, Brazil

${ }^{2}$ Faculdade de Farmácia, Universidade Federal de Juiz de Fora - UFJF, Juiz de Fora, MG, Brazil

${ }^{3}$ Embrapa Gado de Leite Juiz de Fora, Juiz de Fora, MG, Brazil

${ }^{4}$ Laboratório de Corantes Naturais e Compostos Bioativos, Departamento de Tecnologia de Alimentos, Universidade Federal de Viçosa - UFV, Viçosa, MG, Brazil

${ }^{5}$ Departamento de Ciências Biológicas, Universidade Federal de Juiz de Fora - UFJF, Juiz de Fora, MG, Brazil

*Corresponding author: marthaebessa@hotmail.com 
feasible the strengthening of food industry in an increasingly competitive market (Minim et al., 2012).

The DSC is a method allowing to aggregate similar opinions, qualitatively dismembering the individual discourses into fragments representative of the collective thought (Lefèvre \& Lefèvre, 2012). This method accesses the sensory perception and elucidates the consumer's impression respecting to product's acceptance, and his market expectations. The mechanisms able to pick up the consumers' necessities and expectations are tools endowed with power to evaluate the market potentialities (Chapaval et al., 2006; Dimenstein et al., 2010; Ribeiro et al., 2010). Some studies about the outgrowth of fermented caprine milk have been developed; however, it is necessary to give higher emphasis to consumer. Considering the importance of sensory perception and the perspectives of market insertion, this work has been developed with the purpose to improve the fermented caprine milk formulations and evaluate the consumer's response to them.

\section{Materials and methods}

The in natura caprine milk evaluation, that is, crude and the thermally treated milk, was developed according to parameters established at Normative Guideline \# 37, which approves the Technical Regulation for Caprine Milk Identity and Quality (Regulamento Técnico de Identidade e Qualidade de leite de cabra - Brasil, 2000).

\subsection{Microbiological analyses of goat milk}

The microbiological evaluation of the thermally treated milk matrix was developed as described in the $4^{\text {th }}$ Edition of the Compendium of Methods for the Microbiological Examination of Foods - American Public Health Association, 2001).

The microbiological evaluations of fermented milk were developed according to Normative Guideline \# 46 (Brasil, 2007). The viability of microorganisms present at dairy culture, during the storage period, was developed according to Standard Methods for the Examination of Dairy Products (Frank \& Yousef, 2004).

The probiotic bacteria of fermented milk have been identified and listed. The culture of $S$. thermophilus was determined using M17 agar, followed by incubation in anaerobiosis at $37^{\circ} \mathrm{C}$ for $48 \mathrm{~h}$ corresponded to the count existing marketed products meeting regulatory aspects for the dairy industry (Batista et al., 2015). The viability of probiotic dairy cultures L. acidophilus and Bifidobacterium were measured using respectively primary MRS- maltose, followed by anaerobic incubation at $37^{\circ} \mathrm{C}$ for $72 \mathrm{~h}$ and MRS - LP supplemented followed by anaerobic incubation at $37^{\circ} \mathrm{C}$ for 3 days. The mean values obtained in counts were above the minimum established by the scientific community being able to attribute health benefits (Maganha et al., 2014).

\subsection{Physicochemical analyses}

The physicochemical tests were developed according to current legislation for fermented milks (Brasil, 2000). The analyses were done employing the analytical norms anticipated by Adolfo Lutz Institute (Instituto Adolfo Lutz, 2008).

\subsection{Fermented milks manufacture}

The milk was heated up to $90{ }^{\circ} \mathrm{C}$, under constant stirring for 30 minutes; then, it was cooled to $43{ }^{\circ} \mathrm{C}$ for inoculation of cultures composed by microorganisms L. acidophilus LA-5, Bifidobacterium BB-12, and S. thermophilus, associated to Bio Rich $^{\circledR}$ Yeast, in the concentration of $1 \%$. The goat milk fermented with Bio Rich ${ }^{\circledR}$ Yeast was identified as Fermented Milk 1 (Leite Fermentado 1 - LF1). Sample LF2 was processed in the same way as the previous one, but with addition of insulin 3\% (w/v) and saccharose $6 \%(\mathrm{w} / \mathrm{v})$ during the thermal treatment step; and LF3 differs from LF2 by the addition of strawberry pulp.

\subsection{Sensory analysis}

Sensory acceptance tests were developed utilizing the hedonic scale, with 50 untrained tasters. The outlining utilized for the study was at random, 50 volunteer tasters, adults, of both genders, aged between 20 and 60 years, possessing educational level between undergraduate and graduate, and being accustomed to frequent consumption of yogurts based on cows' milk.

The tasters participating in the investigation consume, or have already consumed, products based on goat milk. Individuals with allergic history or intolerance to lactose were excluded from participation in the sensory analyses, as anticipated in the Informed Consent Form (ICF) approved by the Independent Ethics Committee/Institutional Review Board (IRB/IEC Consolidated Opinion \# 525.257).

The hedonic test was conducted using hybrid 9-point scale ( 1 = not enjoyed immensely, 9 = liked a lot) for the attributes of acidity, aroma, flavor and texture (Dantas et al., 2016). Consumers received an evaluation form followed by the sample, they rated the sample for each attribute. The samples were coded with three digit numbers, served in plastic cups and presented in blocks to the tasters (Morais et al., 2014). The test was carried out at Brazilian Agricultural Research Corporation (EMBRAPA, CNP- Gado de Leite, 610 - Eugênio do Nascimento (ST), Juiz de Fora - MG, Brazil) in a single session; between each sample a little water was offered in order to leave the palate clean and free from another flavor that could influence the test. Each consumer decisions were based exclusively on the sensory characteristics of fermented milks offered as product information and formulation were not provided (Cruz et al., 2012).

\subsection{Analysis by the discourse of the collective subject}

The descriptive evaluation of qualitative cutoff was developed by means of structured interviews, being applied to the tasters of fermented goat milk participating in the acceptance test. The interviews average duration was 05 minutes. The applied technique was thematic analysis of discourse, utilizing three methodological figures - the 'Central Idea', the 'Key Expressions', and the 'Discourse of the Collective Subject'.

The DSC methodology was subdivided into several steps, including the utilization of a specific software for methodology application. For the building of collective discourses, the following processes were developed: 
I. Key Expressions: pieces from the testimonies abridging the responses content;

II. Central Ideas: synthetic formulas identifying the senses from every testimony;

III. Categorization: central ideas obtained for every question are characterized by a letter. The software generates a listing of associated central ideas for every referred category;

IV. The DSCs: compilation of Key Expressions present in the subjects' response, which possess central ideas of similar sense. The generic statements from the enunciator's discourse that manifested a given theory or belief were discriminated as anchorage.

The results obtained in the physicochemical and microbiological analyses were statistically calculated by Analysis of Variance (ANOVA), and the averages comparison was developed by Tukey's test with significance level $p \leq 0.05$, utilizing the Assistat 7.7 beta software, register INPI 0004051-2. The data from hedonic sensory analysis were submitted to Analysis of Principal Components (Principal Component Analysis - PCA) (Nunes, 2013). The responses obtained by the methodology of Discourse of the Collective Subject (DSC) were analyzed and submitted to Qualiquantisoft ${ }^{\circledR}$ software.

\section{Results and discussion}

The microbiological analysis of crude milk, evaluated by plate standard count, presented satisfactory results (Brasil, 2000). The analyses of coliforms at $35^{\circ} \mathrm{C}$ and coliforms at $45^{\circ} \mathrm{C}$ resulted in counts lower than $3 \mathrm{NMP}^{\star} / \mathrm{mL}$ for the crude milk samples, absence of Salmonella spp. was also verified; demonstrating so the satisfactory hygienic-sanitary conditions of the goat shed supplying the goat milk utilized in the investigation (Brasil, 2000).

${ }^{*} \mathrm{NMP}=$ Número Mais Provável or most probable number

The analyses done in the developed formulations presented results according to standards established in the current legislation, as demonstrated at Table 1.

The count of S. thermophilus, present in the dairy culture, was according to values established by current Brazilian legislation, which establishes the total count of viable lactic bacteria as, at least, $1 \times 10^{7} \mathrm{CFU} / \mathrm{mL}$ in the final product, during storage period. The count values for the probiotic bacteria Lactobacillus acidophilus LA-5 and Bifidobacterium sp. BB-12 satisfied the parameters established at Normative Guideline \# 46, the starter cultures in all the products were higher than $7 \mathrm{log} \mathrm{cfu} \cdot \mathrm{g}^{-1}$ (Brasil, 2007).

The physicochemical results of fermented milk are found at Table 2 .

There was no significant difference between the values obtained for acidity and $\mathrm{pH}$. The content of fat and proteins in the formulations is according to standards established by the legislation. The proteins concentration and fat content, associated to thermal pre-treatment, favor the product viscosity and positively impact the product sensory evaluation. As higher is the fat content, as denser is the clot; a fact due to influence of
Table 1. Microbiological values obtained in fermented milks (Leites Fermentados - LF) elaborated with goat milk.

\begin{tabular}{|c|c|c|}
\hline $\begin{array}{c}\text { Requisites anticipated } \\
\text { at IN } 37\end{array}$ & $\begin{array}{c}\text { Count in LF1, LF2, } \\
\text { and LF3 samples }\end{array}$ & Acceptance criteria ${ }^{\star}$ \\
\hline Plates standard count & $<3 \mathrm{CFU} / \mathrm{mL}$ & $\begin{array}{l}\text { Maximum } 5 \cdot 10^{4} \\
\mathrm{CFU} / \mathrm{mL}\end{array}$ \\
\hline Coliforms at $35^{\circ} \mathrm{C}$ & $<3 \mathrm{NMP} / \mathrm{mL}$ & $\begin{array}{l}\text { Maximum } 0.4 \bullet 10 \\
\mathrm{NMP} / \mathrm{mL}\end{array}$ \\
\hline Coliforms at $45^{\circ} \mathrm{C}$ & $<3 \mathrm{NMP} / \mathrm{mL}$ & $\begin{array}{l}\text { Maximum } 0.1 \bullet 10 \\
\mathrm{NMP} / \mathrm{mL}\end{array}$ \\
\hline Salmonella spp. & Absence & Absence \\
\hline
\end{tabular}

Table 2. Average values obtained from physicochemical analyses of fermented milks, respecting to parameters anticipated at Normative Guideline \# 46 (Brasil, 2007).

\begin{tabular}{lcccc}
\hline \multicolumn{1}{c}{ Analysis } & LF1 & LF2 & LF3 & IN 46 \\
\hline $\begin{array}{l}\text { Acidity } \\
\text { (g of lactic acid/100 g) }\end{array}$ & $0.73^{\mathrm{a}}$ & $0.74^{\mathrm{a}}$ & $0.75^{\mathrm{a}}$ & 0.6 to 2.0 \\
Fat $(\%)^{*}$ & & & & \\
Protein $(\%)$ & $3.2^{\mathrm{a}}$ & $3.2^{\mathrm{a}}$ & $3.1^{\mathrm{a}}$ & 3.0 to 5.9 \\
$\mathrm{pH}^{*}$ & $3.57^{\mathrm{ab}}$ & $3.52^{\mathrm{b}}$ & $3.64^{\mathrm{a}}$ & Minimum 2.9 \\
Total dry extract & $4.6^{\mathrm{a}}$ & $4.61^{\mathrm{a}}$ & $4.62^{\mathrm{a}}$ & - \\
\hline
\end{tabular}

Averages followed by the same letter in the line are not statistically different each other, at the significance level of 5\%, according to Tukey's Test of Fermented Milk 1 (LF1), Fermented Milk 2 (LF2), and Fermented Milk 3 (LF3). IN 46 = Instrução Normativa $n^{\circ} \mathbf{4 6}$ or Normative Guideline \# 46. ${ }^{*}$ Parameters required by that IN no 46 .

fat percent on the medium content of total solids (Sharker et al., 2000).

The caprine milk possesses low content of $\alpha_{\mathrm{s} 1}$-casein and higher dispersion of casein micelles, forming an almost semiliquid clot when utilized for production of fermented milks. The content of total solids increasing effectively contributes for a satisfactory consistency in the curd (Cenachi \& Pinto, 2012).

The LF3 fermented milk presented higher value of dry extract; there was no significant difference between the LF1 and LF2 samples. In the milk standardization, the rising of total dry extract is obtained by addition of soluble solids, and this procedure when associated to concentration by evaporation, allows increasing the final product viscosity.

Studies have proven a fastness increase of fermented milks as a result of saccharose and soluble solids addition, and after their concentration by evaporation (Cenachi \& Pinto, 2012). The use of inulin, or other fiber present in the fruit pulp also contributes to the improvement of fermented products texture goat (Costa et al., 2015).

Figure 1 demonstrates the viscosity of fermented milks during the evaluated storage period. The samples with addition of soluble solids presented viscosity higher than that of sample LF1, which after the clot breakage presented high fluidity, differing so from the remaining formulations.

The results obtained in the sensory analysis of evaluated samples are found at Table 3 and Figure 2. 
Table 3. Average results $(n=50)$ of sensory acceptance evaluation of fermented milks (LF) samples.

\begin{tabular}{lccc}
\hline Attributes & LF1 $^{\star}$ & LF2 & LF3 \\
\hline Flavor & $6.42^{\mathrm{b}} \pm 0.01$ & $7.14^{\mathrm{b}} \pm 0.01$ & $8.28^{\mathrm{a}} \pm 0.01$ \\
Taste & $4.56^{\mathrm{b}} \pm 0.01$ & $5.2^{\mathrm{b}} \pm 0.01$ & $7.7^{\mathrm{a}} \pm 0.1$ \\
Viscosity & $5.02^{\mathrm{b}} \pm 0.03$ & $5.2^{\mathrm{b}} \pm 0.03$ & $7.78^{\mathrm{a}} \pm 0.02$ \\
Acidity & $6.66^{\mathrm{b}} \pm 0.02$ & $6.84^{\mathrm{b}} \pm 0.02$ & $7.62^{\mathrm{a}} \pm 0.01$ \\
\hline
\end{tabular}

Averages followed by the same letter in the line are not statistically different each other, at the significance level of 5\%, according to Tukey's Test. Fermented Milk 1 (LF1), Fermented Milk 2 (LF2), and Fermented Milk 3 (LF3). ${ }^{*}$ Fermented Milk without addition of fruit pulp.

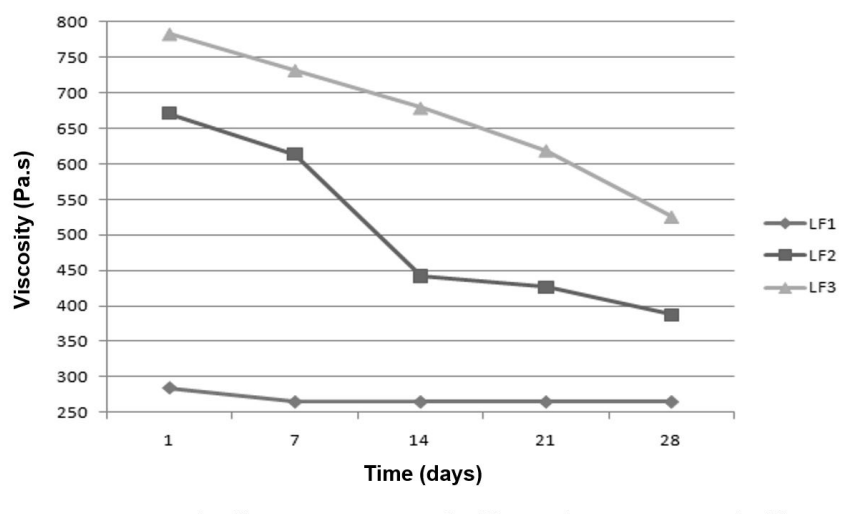

LF1 - Fermented Milk 1, LF2 - Fermented Milk 2, and LF3 - Fermented Milk 3

Figure 1. Average viscosity values during the fermentation period of goat milk, 2014; (LF) Fermented Milk.

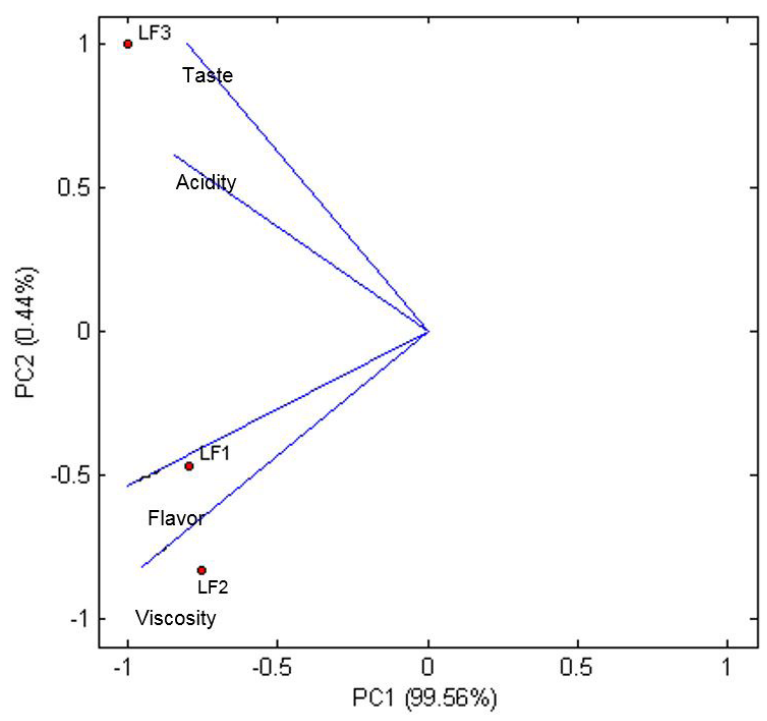

LF1 - Fermented Milk 1, LF2 - Fermented Milk 2, and LF3 - Fermented Milk 3

Figure 2. Biplot between the fermented goat milk samples and the evaluated sensory attributes.

The direction of greater variation - PC1 models $99.56 \%$ of the data matrix, while PC2 explain $0.44 \%$ of the data set variation relating the most significant attributes of the dimensions of data. Cluster analysis using vector model fits the data obtained in the hedonic scale aimed at their reduction, and a representative of shaped (Gaze et al., 2015; Matera et al., 2014).
LF3 sample presented the higher scores of all attributes (flavor, acidity, taste, and viscosity) evaluated in the hedonic scale. LF1 and LF2 samples were not significantly different from each other. The ACP results demonstrate that 'taste' and 'acidity' attributes are correlated to LF3 sample, and the 'flavor' and 'viscosity' attributes to LF1 and LF2 samples.

The average value obtained for the 'flavor' attribute, respecting to LF3 sample, corresponded to "I liked it very much"; and its 'taste' attribute was evaluated as "I moderately liked it". LF1 and LF2 samples presented the evaluation "I mildly liked it" and "I moderately liked it" for 'flavor', and the 'taste' was evaluated as "I neither liked, nor disliked it".

The metabolic products from dairy culture microorganisms influence directly the final product 'flavor' and 'taste.' The culture utilized was the same for all treatments, and insulin and saccharose were added to LF2 sample, to give it sweetness and increase the final product viscosity; however, 'flavor', 'taste', and 'viscosity' distinction has not occurred between LF1 and LF2 samples.

Increased 'acidity' could alter the 'taste' and 'flavor' profile of fermented milks, decreasing the products' acceptability. There was no significant difference in the perception of this attribute for LF1 and LF2 fermented milks. In the ACP, LF3 sample differed from the remaining ones. However, the obtained physicochemical results demonstrated that the titrated 'acidity' of fermented milks was similar, not statistically differing each other.

The attribute 'viscosity', respecting to LF3 sample, corresponded to "I moderately liked it"; and for LF1 and LF2 samples, it corresponded to "I mildly liked it" in the hedonic scale. In the physicochemical analysis, LF1 sample presented 'viscosity' different from that of the remaining ones; however, there was no 'viscosity' differentiation between LF1 and LF2 samples, according to hedonic scale.

Trained tasters presented abilities and perceptions differentiated from those of untrained tasters. For evaluation of consumer's acceptance in a given sample related to another one, the judges were untrained; highlighting so the importance of establishing the target public (Dutcosky, 2011).

The hedonic evaluation and ACP demonstrated that the insulin and saccharose addition has not influenced the 'flavor', 'taste', and 'viscosity' perception by untrained tasters; however, the physicochemical evaluation demonstrates difference between elaborated formulations. The difference perceived by tasters between formulations was noticed only, for the sample with fruit pulp.

Food habits and cultural standards influence directly the food's acceptability by consumers. The consumer perception, examined by DSC, presented substantial differences between developed formulations. The responses from tasters participating in the investigation are presented in the format of Discourse of the Collective Subject (DSC) and organized by answered question, in order to facilitate the comprehension.

The discourses more relevant to understand the applied methodology, or in other words, the discourses presenting higher scores, were selected and presented at Table 4. 
Table 4. Central idea and Discourse of the Collective Subject from 50 sample tasters of the fermented goat milks, produced in this study as a response to the question: "In your opinion, what is the difference between the product you regularly consume and the product you have just tasted?".

Central idea $(1)^{*} \quad$ Discourse of the Collective Subject (1)

"I have noticed that yogurt done with goat milk has a taste in the final. I imagine it is a result from the characteristic taste of goat milk; I think the taste and flavor are both quite different, very peculiar even.

$\begin{array}{ll}\text { Difference is in the typical taste } & \text { characteristic taste of goat milk; I think the taste and flavor are both quite different, very peculiar even. } \\ \text { I noticed a stronger taste; the strawberry flavor dissembles a lot such taste; the goat milk flavor was quite }\end{array}$

$\begin{array}{ll}\text { Difference is in the typical taste } & \text { characteristic taste of goat milk; I think the taste and flavor are both quite different, very peculiar even. } \\ \text { I noticed a stronger taste; the strawberry flavor dissembles a lot such taste; the goat milk flavor was quite } \\ \text { dissembled." }\end{array}$ Central idea (3)* Discourse of the Collective Subject (3)

"I have noticed most the acidity. The difference is that it is a little bit sour, a little bit more acid than that which I regularly consume. I have mainly noticed it in the fermented milks without pulp; the acidity is higher in these products."

Difference is in the acidity

Central idea $(6)^{\star}$

The difference is in the taste and flavor not fermented cows' milk. The taste of both "natural products" is quite strong."

Central idea $(8)^{\star}$

Strawberry taste is good I though its taste is lighter and delights me even more than that I regularly drink."

${ }^{\star}$ It represents the central ideas shared with representativeness higher than $10 \%$ of interviewed tasters, after the acceptance tests of fermented goat milks.

The interviewed persons report in detail differentiated characteristics and sensations. Such a fact allows that, in the product elaboration process, positive points mentioned by the tasters can be considered in the formulation. The interviewed persons who did not like the fermented milks have done justifications about the strong and disagreeable taste, as compared to that of the regularly consumed fermented milk. The negative evaluation was noticed in the anchorage as identified at central idea 1 , contributing so for the product evaluation.

The categorized interviewed persons noticed a typical taste in the fermented milks. This taste was softened at LF3 sample, by the fruits pulp. The ACP analysis has shown the distinction of LF3, related to 'taste' and 'acidity' attributes. Generally, when consumers describe the "taste", they normally are referring to the 'flavor.' The oral mucosa and tongue recognize five tastes: sweet, salted, acid, bitter, and the "umami". The taste is a mixed, but unitary sensation, which is more complex, as it involves other senses (Dutcosky, 2011).

The fermented milks LF1 and LF2 were classified by the tasters as natural, and differentiated themselves in the ACP analysis, for the attributes 'viscosity' and 'flavor'; however, the untrained taster perception in the DSC considered the 'flavor' and 'taste' attributes as pleasant in all the samples, with distinction for LF3. The strawberry taste disguises the typical caprine milk taste, improving the product acceptability. A similar result was obtained by Costa et al. (2014), the addition of fruit pulp increased sensory acceptance of the fermented goat's milk.

The processed fermented goat's milk maintains its original and characteristic taste; the fruit pulp incorporation benefits the milk flavor and taste decrease, contributing so to improve the product sensory characteristics (Marinho et al., 2012). This perception was noticed by the tasters, and reported in the DSC methodology application. The techniques that evaluate consumer perception as the method "pivot profile", gained ground in the field of sensory evaluation by presenting high correlation results with the classical descriptive methods (Fonseca et al., 2013).
The higher intensity of acid taste was pointed in LF1 and LF2 formulations. The acidity of LF3 sample was considered lower than that of frequently consumed fermented milks. The interviewed persons reported the motive by which they could consume the product, and which are the factors influencing their consumption decision. The obtained discourses allowed to know the consumers' profile, outline the strategic formulation, and gave a marketing direction to fermented milk commercialization. To better understand the wants and needs of consumers and product guarantee of success, Cruz et al. (2013) describe the use of descriptive sensory methodologies in the early stage of product development with multivariate profiles as probiotic yogurts.

Five reports have been obtained, and the reports presenting the higher scores are demonstrated at Table 5.

The DSC has indicated important points for the dairy market, as the interviewed persons emphasized the nutritional characteristics, the better product acceptance thanks to fruits pulp inclusion in the formulation, and the product price as characteristics influencing the acquisition recommendation by consumers. The pulp taste chosen for this product proves the strawberry pulp acceptability by different groups of persons, as well as its representativeness in the formulations of products addressed to dairy market as a function of its popularity (Oliveira, 2009). The wealth of information generated by the DSC application allows you to access a different cognitive interpretation of consumers since it does not limit the selection response or a specific evaluation. The questionnaire was able to generate additional and complementary interpretations of the classical methods (Santos et al., 2015).

The tasters perceived the typical taste of caprine milk; however, the intention of acquisition revealed by DSC was expressive for all fermented milks, revealing so the public expectation for this product. The goat's milk yogurt is an excellent source of nutrients and fatty acids, however the acceptance by consumers is limited because of its typical taste. The repeated exposure technique in food products with rejection history was employed in the study by Costa et al. (2014) with fermented goat milk probiotic with satisfactory results of consumer acceptance. 
Table 5. Central idea and Discourse of the Collective Subject from 50 sample tasters of the fermented goat milks, produced in this study as a response to the question: "Talk me about the possibility for you acquire, or recommend the acquisition of this product, if it is available in the market."

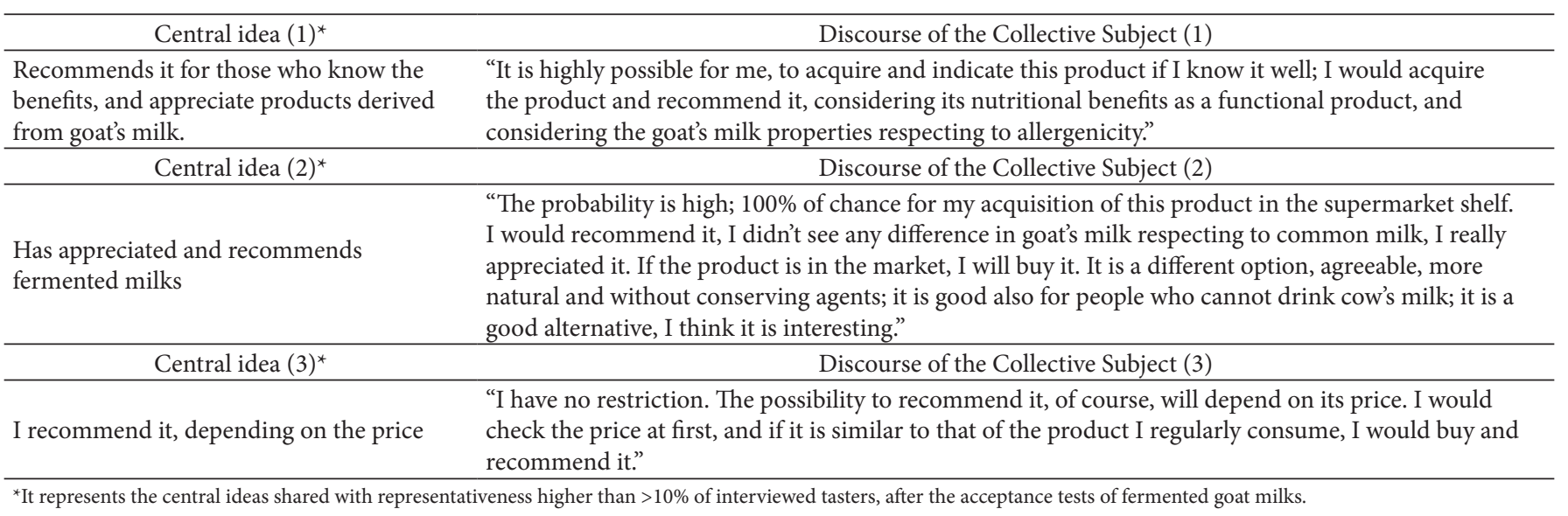

The multidimensional perception of sensory attributes is an application limitation for proposed new methodologies, the DSC methodology demonstrated a perception disassociated from consumers to different sensory attributes correlated in the hedonic scale (Pereira et al., 2016). The semi-structured technique employed in this study, allowed to evaluate the consumer expectations respecting a given product, because the interviewed persons talked about the proposed theme without any interviewer interference. The method enables the comprehension of acceptance, or not, of peculiar characteristics attributed to fermented goat's milk, as it becomes more clear and expressive the social representations, allowing the developed study group to become emitter of common discourses identified in the sharing of similar central ideas (Lefèvre \& Lefèvre, 2005).

\section{Conclusion}

The addition of soluble solids, and the concentration by evaporation, affected the rheological parameters and increased the viscosity of fermented milks, influencing so the formation of a firm clot during the fermentative process.

The nutritional characteristics of fermented goat's milk have positively influenced the consumption decision for elaborated products. The formulation with fruit pulp expressed better acceptance, being that the typical flavor and taste of caprine milk has not influenced the consumers' intention of acquisition.

The DSC has been demonstrated as an important tool for identification of consumers' profile and the factors involved in the acquisition process of fermented goat's milk, serving also to determine its potentiality for inclusion in the dairy market.

\section{Acknowledgements}

The authors are gratefull to Fundação de Amparo à Pesquisa do Estado de Minas Gerais (FAPEMIG), Embrapa Gado de Leite - Juiz de Fora and to Laboratório de Análises de Alimentos e Águas - LAAA of Pharmacy Faculty of the Juiz de Fora Federal University.

\section{References}

Almeida, J. F., Leitão, C. H. S., Nascimento, E. R., Vieira, K. C. M., Alberto, E. M., \& Almeida Pereira, V. L. A. (2009). Avaliação físico-química do leite de cabra in natura em alguns rebanhos de Minas Gerais e Rio de Janeiro, Brasil. Ciência Animal Brasileira, 1, 749-753. Retrieved from: http://revistas.bvs-vet.org.br/cab/article/ view/24426/25309

Alves, H. J., \& Boog, M. C. (2007). Comportamento alimentar em moradia estudantil: um espaço para promoção da saúde. Revista de Saúde Pública, 41(2), 197-204. http://dx.doi.org/10.1590/S003489102007000200005 . PMid:17384793.

American Public Health Association - APHA. (2001). Compendium of methods for the Microbiological Examination of Foods (4th ed., 676 p.). Washington: APHA.

Apás, A. L., Arena, M. E., Colombo, S., \& González, S. N. (2015). Probiotic administration modifies the milk fatty acid profile,intestinal morphology, and intestinal fatty acid profile of goats. Journal of Dairy Science, 98(1), 47-54. http://dx.doi.org/10.3168/jds.20137805. PMid:25465559.

Batista, A. L., Silva, R., Cappato, L. P., Almada, C. N., Garcia, R. K., Silva, M. C., Raices, R. S. L., Arellano, D. B., Sant'Ana, A. S., Conte, C. A. Jr., Freitas, M. Q., \& Cruz, A. G. (2015). Quality parameters of probiotic yogurt added to glucose oxidase compared to commercial products through microbiological, physical-chemical and metabolic activity analyses. Food Research International, 77, 627-635. http:// dx.doi.org/10.1016/j.foodres.2015.08.017.

Brasil, Ministério da Agricultura, Pecuária e do Abastecimento. (2000, Nov 8). Aprova regulamento técnico de produção, identidade e qualidade de leite de cabra (Instrução Normativa no 37 , de 31 de outubro de 2000). Diário Oficial da União.

Brasil, Ministério da Agricultura, Pecuária e Abastecimento. (2007, Oct 24). Regulamento técnico de identidade e qualidade de leites fermentados (Instrução Normativa n 46, de 23 de outubro de 2007). Diário Oficial da União.

Cenachi, D. B., \& Pinto, M. A. O. (2012). Desenvolvimento de leite de cabra fermentado com baixo teor de lactose adicionado de $\beta$-ciclodextrina. Revista do Instituto de Laticínios Cândido Tostes, 67(388), 79-80. http://dx.doi.org/10.5935/2238-6416.20120069.

Chapaval, L., Oliveira, A. A. F., Alves, F. S. F., Andrioli, A., Araujo, A. M., Olivindo, C. S. (2006). Manual do produtor de cabras leiteiras (214 p.). Viçosa: Aprenda Fácil. 
Costa, M. P., Balthazar, C. F., Franco, R. M., Mársico, E. T., Cruz, A. G., \& Conte, C. A. Jr. (2014). Changes in expected taste perception of probiotic and conventional yogurts made from goat milk after rapidly repeated exposure. Journal of Dairy Science, 97(5), 26102618. http://dx.doi.org/10.3168/jds.2013-7617. PMid:24582442.

Costa, M. P., Frasão, B. S., Silva, A. C. O., Freitas, M. Q., Franco, R. M., \& Conte, C. A., Jr. (2015). Cupuassu (Theobroma grandiflorum) pulp, probiotic, and prebiotic:Influence on color, apparent viscosity, and texture of goat milk yogurts. Journal of Dairy Science, 98(9), 59956003. http://dx.doi.org/10.3168/jds.2015-9738. PMid:26188580.

Cruz, A. G., Cadena, R. S., Castro, W. F., Esmerino, E. A., Rodrigues, J. B., Gaze, L., Faria, J. A. F., Freitas, M. Q., Deliza, R., \& Bolini, H. M. A. (2013). Consumer perception of probiotic yogurt: Performance of check all that apply (CATA), projective mapping, sorting and intensity scale. Food Research International, 54(1), 601-610. http:// dx.doi.org/10.1016/j.foodres.2013.07.056.

Cruz, A. G., Cadena, R. S., Faria, J. A., Bolini, H. M., Dantas, C., Ferreira, M. M., \& Deliza, R. (2012). PARAFAC: adjustment for modeling consumer study covering probiotic and conventional yogurt. Food Research International, 45(1), 211-215. http://dx.doi.org/10.1016/j. foodres.2011.09.031.

Dantas, A. B., Jesus, V. F., Silva, R., Almada, C. N., Esmerino, E. A., Cappato, L. P., Silva, M. C., Raices, R. S., Cavalcanti, R. N., Carvalho, C. C., Sant'Ana, A. S., Bolini, H. M., Freitas, M. Q., \& Cruz, A. G. (2016). Manufacture of probiotic Minas Frescal cheese with Lactobacillus casei Zhang. Journal of Dairy Science, 99(1), 18-30. http://dx.doi.org/10.3168/jds.2015-9880. PMid:26519974.

Dimenstein, R., Melo, C. U., Garcia, L. R. S., \& Lira, L. Q. (2010). Quantificação do retinol em leite de cabra e sua importância na alimentação infantil. Revista do Instituto Adolfo Lutz, 69(3), 415418. Retrieved from: http://bases.bireme.br/cgi-bin/wxislind.exe/ iah/online/?IsisScript=iah/iah.xis\&src=google \& base=LILACS $\&$ lang=p\&nextAction=lnk\&exprSearch=583064\&indexSearch=ID

Dutcosky, S. D. (2011). Análise sensorial de alimentos (3rd ed., pp. 32321, Coleção Exatas, Vol. 4). Curitiba: Champagnat.

Fonseca, C. R., Bordin, K., Fernandes, A. M., Rodrigues, C. E. C., Corassin, C. H., Cruz, A. G., \& Oliveira, C. A. F. (2013). Storage of refrigerated raw goat milk affecting the quality of whole milk powder. Journal of Dairy Science, 96(7), 4716-4724. http://dx.doi. org/10.3168/jds.2012-6120. PMid:23664351.

Frank, J. F., \& Yousef, A. E. (2004). Tests for groups of microrganisms. In H. M. Wehr \& J. F. Frank. Standard methods for the examination of dairy products (17th ed., chap 8, pp. 227-247). Washington: American Public Health Association. Section 8.701.

Gaze, L. V., Oliveira, B. R., Ferrao, L. L., Granato, D., Cavalcanti, R. N., Conte, C. A., Jr., Cruz, A. G., \& Freitas, M. Q. (2015). Preference mapping of dulce de leche commercialized in Brazilian markets. Journal of Dairy Science, 98(3), 1443-1454. http://dx.doi.org/10.3168/ jds.2014-8470. PMid:25557891.

Instituto Adolfo Lutz - IAL. (2008). Métodos físico-químicos para análise de alimentos (1st ed., 1020 p.). São Paulo: Instituto Adolfo Lutz.

Lefèvre, F., \& Lefèvre, A. M. C. (2005). O Discurso do Sujeito Coletivo: um novo enfoque em pesquisa qualitativa: desdobramentos (2nd ed.). Caxias do Sul: EDUSC.

Lefèvre, F., Lefèvre, A. M. C. (2012). O Discurso do Sujeito Coletivo e o resgate das coletividades opinantes. São Paulo: Instituto de Pesquisa do Discurso do Sujeito Coletivo.
Maganha, L. C., Rosim, R. E., Corassin, C. H., Cruz, A. G., Faria, J. A., \& Oliveira, C. A. (2014). Viability of probiotic bacteria in fermented skim milk produced with different levels of milk powder and sugar. International Journal of Dairy Technology, 67(1), 89-94. http://dx.doi. org/10.1111/1471-0307.12087.

Marinho, M. V. M., Figueirêdo, R. M. F., Queiroz, A. J. M., Santiago, V. M. S., \& Gomes, J. P. (2012). Análise fisico-química e sensorial de iogurte de leite de cabra com polpa de umbu. Revista Brasileira de Produtos Agroindustriais, 14(Especial), 497-510. http://dx.doi. org/10.15871/1517-8595/rbpa.v14nEspecialp497-510.

Matera, J. A., Cruz, A. G., Raices, R. S. L., Silva, M. C., Nogueira, L. C., Quitério, S. L., Cavalcanti, R. N., Freiras, M. Q., \& Conte, C. A. Jr. (2014). Discrimination of Brazilian artisanal and inspected pork sausages: application of unsupervised, linear and non-linear supervised chemometric methods. Food Research International, 64, 380-386. http://dx.doi.org/10.1016/j.foodres.2014.07.003.

Minim, V. P. R., Milagres, M. P., Silva, R. C. S. N., Vasconcelos, C. M., Martins, E. M. F., \& Sampaio, S. C. S. A. (2012). Análise de risco na avaliação da influênciada marca na aceitabilidade não sensorial de requeijão cremoso. Revista do Instituto de Laticínios Cândido Tostes, 67(387), 79-85. http://dx.doi.org/10.5935/2238-6416.20120053.

Morais, E. C., Morais, A. R., Cruz, A. G., \& Bolini, H. M. A. (2014). Development of chocolate dairy dessert with addition of prebiotics and replacement of sucrose with different high-intensity sweeteners. Journal of Dairy Science, 97(5), 2600-2609. http://dx.doi.org/10.3168/ jds.2013-7603. PMid:24612793.

Nunes, C. A. (2013). Chemoface v.1.5. Lavras: Universidade Federal de Lavras. Software.

Oliveira, M. N. (2009). Tecnologia de produtos lácteos funcionais (pp. 124-343). São Paulo: Atheneu.

Pereira, E. P. R., Cavalcanti, R. N., Esmerino, E. A., Silva, R., Guerreiro, L. R. M., Cunha, R. L., Bolini, H. M., Meireles, M. A., Faria, J. A., \& Cruz, A. G. (2016). Effect of incorporation of antioxidants on the chemical, rheological, and sensory properties of probiotic petit suisse cheese. Journal of Dairy Science, 99(3), 1762-1772. http:// dx.doi.org/10.3168/jds.2015-9701. PMid:26805976.

Ribeiro, M. M., Minim, V. P. R., Minim, L. A., Arruda, A. C., Ceresino, E. B., Carneiro, H. C. F., \& Cipriano, P. A. (2010). Estudo de mercado de iogurte da cidade de Belo Horizonte/MG. Revista Ceres, 57(2), 151-156. http://dx.doi.org/10.1590/S0034-737X2010000200003.

Santos, B. A., Campagnol, P. B., Cruz, A. G., Galvão, M. T. E. L., Monteiro, R. A., Wagner, R., \& Pollonio, M. A. R. (2015). Check all that apply and free listing to describe the sensory characteristics of low sodium dry fermented sausages: comparison with trained panel. Food Research International, 76, 725-734. http://dx.doi.org/10.1016/j. foodres.2015.06.035.

Sharker, R. R., Jumah, R. Y., \& Abu-Jdayil, B. (2000). Rheological properties of plain yogurt during coagulation process: impact of fat content and preheat treatment of milk. Journal of Food Engineering, 44(3), 175-180. http://dx.doi.org/10.1016/S0260-8774(00)00022-4.

Villalobos, A. C. (2005). Aspectos nutricionales de la leche de cabra (Capra hircus) y sus variaciones em el proceso agroindustrial. Agronomía Mesoamericana, 16(2), 239-252. http://dx.doi.org/10.15517/ am.v16i2.11878. 